\title{
Right-Wing Populism and Safe Identities
}

Rosemary Lobban ${ }^{\mathrm{a}}$, Russell Luyt ${ }^{\mathrm{b} *}$, Sam Martin ${ }^{\mathrm{c}}$, Ashley Brooks ${ }^{\mathrm{d}}$, Daragh McDermott $^{\mathrm{e}}$ \& Magdalena Zawisza ${ }^{\mathrm{f}}$

${ }^{a \& b}$ School of Human Sciences, University of Greenwich, London, UK; ${ }^{c, d, e \& f}$ School of Psychology and Sport Science, Anglia Ruskin University, Cambridge, UK

*School of Human Sciences, University of Greenwich, Old Royal Naval College, Park Row, London SE10 9LS, United Kingdom. Email: r.luyt@gre.ac.uk 


\section{Right-Wing Populism and Safe Identities}

\section{Introduction}

Divisive right-wing populists such as Viktor Orbán (Hungary), Narendra Modi (India), Vladimir Putin (Russia) and Donald Trump (United States) have heralded the reemergence of non-egalitarian ideologies in dominant public discourse. Populism, as generally operationalised in this paper, is defined as a right-wing politics that 'combine(s) attacks on socially oppressed groups with grassroots mass mobilization and distorted forms of antielitism based on scapegoating' (Berlet \& Lyons, 2000, p. 1). Populists take grievances and turn them into crises that demand immediate, often reductionist, solutions. These solutions are frequently disempowering for minority groups, who are framed as competitors responsible for the withdrawal of resources from 'once dominant' groups; 'the surge in votes for populist parties can be explained [...] in large part as a reaction against progressive cultural change' (Inglehart \& Norris, 2016, pp. 2-3). It is perhaps unsurprising then that traditional cultural values predict voting support for such figures (ibid.), as do anti-immigration attitudes (Kentmen-Cin \& Erisen, 2017). Yet the emergence of grassroots political movements such as 'Gays for Trump' (see http://gaysfortrump.org/) and ‘\#WomenWhoVoteTrump’ suggest more complex patterns of support.

Some might expect that traditionally disadvantaged groups such as women and sexual minorities would reject right-wing populism, as it would seem to facilitate their oppression. In Trump's case, neglect of women's interests is evident in relation to abortion rights (Wolffe, 2018) and sexual abuse (Cranley \& Mark, 2018). Lack of support for gay men's interests is also apparent, for instance in Trump's proposed budget cuts to HIV research and prevention, which disproportionately impacts sexual minority men. Yet the existence of movements like '\#WomenWhoVoteTrump' and 
'Gays for Trump' suggests an apparent reaction against progressive cultural changes by the very groups who stand to benefit from them. It therefore seems likely that there are benefits, real or imagined, to disadvantaged group members' endorsement of right-wing populism. These benefits, it is argued here, are tied to identities in dialogue with progressive cultural change.

This paper presents the proceedings of a round table discussion which took place at the Political Masculinities and Populism Conference in December 2017. Our contributors, members of a cross-institutional Gender and Sexualities Research Group, each presented a five-minute interpretation of the phenomenon and subsequently took part in a chaired discussion. They did so from varying gender and/or sexualities perspectives, drawing differentially upon social psychological theory.

The differences in perspective most clearly manifest in disagreement concerning the nature of identity and whether it is best accounted for as an individual attribute or characteristic (as advocated by Ashley Brooks, Daragh McDermott and Magdalena Zawisza-Riley) or a social practice (as proposed by Russell Luyt and Sam Martin). This disagreement has broader ontological and epistemological implications, many of which have been well-rehearsed since the 'crisis in social psychology' from late 1960's in which social psychology's uncritical adoption of natural science's realist-positivist paradigm was challenged (Parker, 1989). Russell Luyt and Sam Martin argue that identities and, relatedly, masculinities and political views, are actively constructed in situated interaction for specific functions. This being the case, when women and sexual minorities express support for right-wing populists, they are doing something, for instance strategically adopting particular identity positions. They may be doing so for a variety of reasons, for example, to avoid criticism or achieve social reward (Potter \& Wetherell, 1987). Other contributors argue that identity, masculinity and political views 
are attributes or characteristics of the individual which remain relatively consistent across context and lifespan. From this perspective, in order to effect behavioural change, it makes sense to try and predict how people will behave based on their relatively stable characteristics. This perspective has given rise to a tranche of studies focussing on predictors of populist support including cognitive ability, authoritarianism (Choma \& Hanoch, 2016), collective narcissism (Marchlewska, Cichocka, Panayiotou, Castellanos \& Batayneh, 2018), and a range of other social psychological constructs (e.g., Pettigrew, 2017), as well as experimental studies where variables such as group status threat are manipulated (e.g., Major, Blodorn \& Blascovich, 2016).

In speaking to these various concerns, the panel contributions facilitated breadth of enquiry. Depth was achieved through this paper's subsequent identification of key themes arising from contributions and audience discussion. In this sense, the round table may be viewed as an exercise in data collection, where subsequent analysis sought to identify common and diverging themes within the data. These were determined using inductive social constructionist thematic analysis (Braun \& Clarke, 2006).

In sum, this paper aims to provide novel insights into support for right-wing populism amongst women and sexual minorities. It does so by drawing upon diverse perspectives within social psychology in order to identify areas of convergence, as represented by various themes. These themes are then considered in terms of the extant literature.

Three themes were identified: 'threatening identities'; 'safety through the status quo'; and 'safe academic identities'. All related to notions of 'identity' and 'safety'; hence an overarching theme of 'safe identities'. These three themes are described with reference to the panel contributions, presented in full below, and subsequent debate. 


\section{Panel contributions}

\section{Ashley Brooks}

'In the aftermath of Trump being elected US president, exit poll data (CNN, 2016) suggests that he received about $14 \%$ of the LGBTQ+ vote. This represents a reduction from the previous election where about $22 \%$ of the LGBTQ+ vote went to the republican candidate, Mitt Romney. But given the size of the LGBTQ+ population in the US, it still represents a large number of LGBTQ+ people (McDonald, 2016). This continued support is surprising. Evidently, Trump appealed to these voters in some way, and this doesn't make sense on the face of it given some of his seemingly anti-LGBTQ+ policies and actions both before and since he was elected. Nonetheless, he has developed a very vocal following of gay men, who seem to perceive two main threats. The first is radical Islam in which the Muslim faith is perceived to represent a fundamental danger to LGBTQ+ people. Trump has actively courted this view by, for example, proposing travel bans on majority Muslim countries.

Secondly - and what I will be focussing most on here - is the threat of "liberals". I am not referring to any formalised or academic definition of liberals but, rather, to a representation of an extreme political left that is intolerant, anti-empiricist, pro-experiential, and ideologically dangerous. Brandon Straka, a gay former Democrat supporter who recently founded the \#WalkAway movement to encourage Democrats to abandon this depiction of liberalism, characterises this well (Fitzsimons, 2018). This threat is understood particularly in terms of their perceived paternalism in their attempts to protect and defend LGBTQ+ people, but in so doing, diminishing their autonomy and agency. This is a belief that has spawned a number of epithets for liberals such as “special snowflakes"; people who are easy to offend, upset, or "trigger". Such mockery 
is perhaps prompted through specific paternalistic actions meant to protect LGBTQ+ people from discrimination, for instance "no-platform policies" that bar speakers with arguably oppressive views from communicative platforms such as university student societies. While this aims to protect minority groups from the perceived harm of (potentially hateful) speech, it is paternalistic because it impacts upon the speaker's agency for the benefit of others and the audience's agency for their own benefit (Shiffrin, 2000).

In qualitative data that I collected in 2015 (Brooks, Luyt, Zawisza \& McDermott, Submitted), I investigated the ways in which well-meaning people - in an effort to present themselves as liberal and tolerant - are experienced as patronising and demeaning by gay men through over-emphasising gay men's powerlessness and lack of resilience. The focus at the time was on potentially harmful "microaggressive" (Sue, 2010) acts of paternalism rather than protective paternalism within LGBTQ+ activism, and it wasn't until recently that I took an interest in the anti-paternalistic sentiments of LGBTQ+ conservatives engaged with Trump's populism. This has challenged my own taken-for-granted notions of what it means to be pro-LGBT because, as a liberal researcher, I believe I am acting on behalf of the best interests of LGBTQ+ people - yet I invoke paternalism to achieve this. So, to return to my aim of making sense of "Gays for Trump", I disagree that this is akin to "turkeys voting for Christmas"; these voters believe that they are best served by Trump and I argue that framing anti-paternalism as empowerment and rejecting "liberalism" is an aspect of this'.

\section{Russell Luyt}

'It is important to remember that Trump does not represent the "hegemonic" nor is he an exemplar of "hegemonic masculinity". Whilst we might imagine the challenge he 
poses to the hegemonic masculine ideal, indeed even the potential changes to this ideal that may result from this, his gender practices do not yet (re)present what Raeywn Connell describes as a "global hegemonic masculinity" - transnational businessman masculinity (Connell, 1998). This observation resonates with what Christian Norocel (2017) was describing as the paradoxes of right-wing populism. Trump, of course, embodies these paradoxes in claiming to be the voice of the white working class, who are seemingly disadvantaged by a corrupt elite, whilst in fact being privileged as member of this elite himself. Trump allows us to understand these paradoxes and how they are reconciled by, for instance, the concept of superordinate social identity (Tajfel \& Turner, 1986).

We might start by drawing upon Connell's (1987) well-rehearsed theoretical framework, and specifically her reading of Habermas' (1975) concept of “crisis tendencies", as a key element in the slow (re)production of the gender order. This body of work suggests that the gender order and its defining hegemonic masculine ideal are constantly being challenged, and challenge over time leads to change. In the case of hegemonic masculinity, this has been described as a process of "hybridisation" (Demetriou, 2001). And yet there's something very distinct about the challenge and change that's occurring more recently in the global gender order, and associated political orders, upon which hegemonic masculinity sits at the ideological apex. What we see is not a feature of ongoing crisis tendencies of the gender order. Rather we might better understand these challenges and changes as a crisis in the gender order itself.

A new hegemonic ideal is potentially being instantiated to the extent that the existing gender order, which is intertwined so closely with neoliberalism, is being challenged. And this, to my mind, is enormously worrying. But why should we find challenge to this order worrying? Surely such change should be welcomed. My answer 
is that it is not change per se that is worrying, but the nature of the challenge. The challenge to the gender order that is holding sway, or is dominant today, is not a "progressive" challenge. When we think about challenge and change to the gender order, we implicitly assume that it is positive, progressive challenge and change. But challenge and change today risks being retrogressive. It is a retrogressive challenge that is shaping the global gender order and our immediate future. We see the rise of "charismatic strongmen" who reject evidenced objectivity in favour of supposedly bold “common-sense solutions” (Mudde \& Rovira Kaltwasser, 2017, p. 64).

We have spent much time focussed on right-wing populism (and the likes of Trump). This deserves our attention (and perhaps at times our disdain). And yet our efforts may be displaced. In our labours to challenge hegemonic masculinity, and thereby bring about positive change, we sometimes lose sight of the fact that we, as the "intelligentsia", are often act merely as members of the hegemonic elite. As Gramsci (1929-1935, 1996) helpfully instructs, the ruling class produces a definition of the social world through its deputies - the intelligentsia - where leadership is key to developing a consensual understanding of the world. On this basis, I ask: Are we not part of the problem? To what extent have we failed to offer progressive leadership in the form of organic intellectuals - those who work to lead change through the support of, and for, the disadvantaged?

Are we collectively failing to lead challenge and change in a progressive fashion? Such change calls for more than simply challenge from the side-lines that is seemingly easily hybridised so as to maintain the hegemonic ideal and gender order. Whilst recognising the structural impediments to organic intellectualism (e.g., conventions for progression through peer reviewed publication rather than political intervention), it calls for more revolutionary challenge: one in which we are asked to 
recognise our own interests in and complicity with neoliberalism, not least of which through the material and psychological (identity) dividend which we accrue, that reinforces the comfortable neoliberal assumption of our inhabiting a post-political world determined by cost-benefit analyses alone (Glaser, 2018); one that recognises the common disadvantages that bind the superordinate social identity of those who support right-wing populism; one that challenges the disadvantaged to consider their perceived disempowerment as, fundamentally, a result of neoliberalism rather than other disadvantaged groups'.

\section{Sam Martin}

'I will adopt a social constructionist perspective, and will specifically consider how, why, and what subject positions are made available to people in talk. Stewart, Mazzoleni and Horsfield (2003) observe that populist figures are often represented as being "one of the people" and "just like you". These discourses have been reproduced in a number of advertisements and campaign messages, e.g., Pauline Hanson's One Nation Party using the tag lines "Just an ordinary Australian" and "at one with the ordinary people" (Rapley, 1998). The idea of being "just like you", this kind of "ordinary position" (Sacks, 1984) is something I find really interesting - how people make claims to being "ordinary" and what this accomplishes in talk. I believe the questions we should be asking are, "What does it mean to be ordinary?" and "How does this relate to populist figures who claim to be ordinary and to masculinity?"

I conducted research with queer male and non-binary youth and asked them questions in relation to their gender and sexual identities, and the prejudice they experience on a day-to-day basis. Frequently, the participants made claims to being “ordinary" and "just like you”. Occupying this "ordinary position" contrasted with other 
people that are not "ordinary"; setting up an "us" and "them", and interestingly, "othering" different communities within the wider LGBTQ+ community. So, perhaps LGBTQ+ individuals, and possibly women, support Donald Trump and other populist ideologues because the idea of being "ordinary" and staking a claim to being "ordinary" holds the potential to accrue more rights by being "just like everyone else". This also relates to Duggan's (2002) concept of "homonormativity", where the priority for groups of LGBTQ+ people is to fit into the heteronorm in order to gain the same rights and acceptance as heterosexuals. In particular, discourses of "sameness" and "no difference" were a key feature of arguments in campaigns for equal marriage, both in the USA and UK (Ghaziani, Taylor \& Stone, 2016).

Consider, for example, the following extracts from focus groups I conducted on experiences of prejudice:

Cisgender gay male (21): . . like yeah, the feminists that just take things too far, like they hate all men. "Feminazis" I call them. Yeah, then there's that stuff, it's like, oh yeah there's like 150 genders and you should memorise them all, and you should just accept every one.

Trans male (17): . . . people at school, they're like, “Oh there are all these like trans people, oh", they're all like, "Oh you need to respect my pronouns and learn all these genders and I'm gonna test you on them ... I'm constantly trying to like prove myself', like I'm not like that I'm just chill.

Here we find examples including a cisgender gay man and a trans man othering nonbinary identities from the position of taking things "too far". The cisgender gay man constructs a threatening group of "feminazis". The participant in the second excerpt positions himself as "chill" compared to inflexible gender radicals, in order to legitimise 
his identity in light of normative attitudes. He accomplishes this by attacking other "unordinary" groups; by positioning himself as more ordinary. This is a very attractive and popular rhetorical position for LGBTQ+ individuals, in that it works against the threat of gender radicals dismantling "safe", "ordinary" identities. We are increasingly seeing this with groups of cisgender women turning on transgender women as the threatening "other" (Jeffreys, 2014) and we see it with groups of gay men turning on effeminate gay men (Clarke \& Smith, 2015).'

\section{Daragh McDermott}

'I will consider the political context of the Republic of Ireland. I am interested in the case of Leo Varadkar, the Republic's current Taoiseach, who I argue represents a conservative-leaning, gay, populist leader - one who appears to adopt politically motivated "safe identities".

Within Ireland, homosexuality was decriminalised in 1993 and the country now has an openly gay Taoiseach. He is also the son of an immigrant. In many respects, Ireland's current leader represents a post-Catholic, post-conservative position for the Republic; this is a progressive picture for what once was considered to be the bastion of Catholic conservatism in Europe (Röder, 2017). When you look at Varadkar, contradictions are apparent: yes, he represents a new, progressive politics in the fact that he is a political leader who has "come-out" as gay. However, this image does not fit with the traditional "family values" trope, often utilised by right-wing politicians who play on this aspect of their identity as a mechanism to engender electoral support (Arbour \& McGowen, 2017).

You have a man who presents himself as openly gay, and, in some respects, as socially liberal, particularly in relation to his own personal life. However, as a 
politician, his positions are less clear, and his positionality tends to adapt depending on what is politically expedient. He represents Fine Gael, a traditionally centrist-right political party which has been required by the electorate to adopt more socially progressive policy positions in recent years, for example, support for the same-sex marriage referendum of 2015 (Spillane, 2015). Whilst many of his party campaigned against this referendum, Varadkar publicly "came out" and self-identified as a gay man on national broadcast radio and subsequently personally endorsed the "yes" vote in the same-sex marriage referendum; he made a very calculated political move both personally and within his own party to do so. However, he did so at a time when polling indicated widespread support for a "yes" vote. He therefore profited on popular public opinion and positioned himself as a poster child for the "yes" campaign, despite his party traditionally holding more conservative views.

But perhaps Varadkar is not the socially "liberal-lion" he might want to present as. Ryan and O'Connor (2018) go so far as to say that he is a "politician desperate to force his conservative views on an increasing liberal country" (p. ii). He is preeminently, fiscally neoliberal and he believes in open and free-trade markets. As Minister for Social Protection, he led a very strong and quite draconian campaign to target welfare fraud, particularly by immigrants; again, slightly ironic, being the son of an immigrant (Ryan \& O’Connor, 2018; Varadkar, 2017). Such policies appeal to the elderly, rural and traditional base of the Fine Gael party.

So, what does Varadkar's endorsement of both social liberalism and economic conservativism suggest? Well, to my mind he represents a leader who actively draws upon populist tropes; he will say what he needs to say, when he needs to say it, in order to engender the support that he requires to secure and maintain power (Mudde, 2004). Recent work informed by self-categorisation theory and social identity theory frames 
leadership as a group process and acknowledges the advantages of adopting such a strategy: gaining political power involves representing one's self and one's position as representing group interests (Reicher, 2012). In adopting contradictory stances and by leveraging his attributes, Varadkar positions himself as an appealing option for a range of group interests. Thus, he adopts "safe" positions that serve to maintain and extend his support base and has done so throughout his career (Ryan \& O'Connor, 2018). In doing so, he retains his position and strengthens his influence'.

\section{Magdalena Zawisza-Riley}

““\#WomenWhoVoteTrump” seems a puzzling phenomenon given Trump's widely reported misogynism. According to CNN exit polls (2016), 42\% of women voted for Trump. However, whilst 53\% of white women voted for Trump - 62\% amongst white women from blue-collar backgrounds - the vast majority of black women voted for Hillary Rodham Clinton (94\%). We might ask ourselves, why would any woman vote for Trump at all?

Let's take a moment to define "misogyny". In the words of satirist Henry Mencken (1916, p. 51), "a misogynist is a man who hates women as much as women hate one another". Perhaps then white women tend to be inherently misogynistic and this is why they voted Trump? The issue is likely much more complex. Social psychologists have offered "ambivalent sexism” (Glick \& Fiske, 1996) as a possible framework through which the "\#WomenWhoVoteTrump" movement may be explained.

According to Ambivalent Sexism Theory, attitudes to women are not purely negative as was initially assumed. Instead, people are often ambivalent - they hold both hostile and benevolent attitudes. Hostility amounts to overt negativity. Benevolence, conversely, is seemingly positive in tone. It manifests, for example, in chivalrous 
attitudes which, while positive on the surface, can be damaging as they assume that women are weaker and need help. Empirical evidence shows that the two forms of sexism correlate positively (Glick \& Fiske, 1996). Moreover, the two ideologies serve to maintain the status quo (Glick \& Fiske, 2011). Hostile sexism punishes transgressions from the norm - i.e. from the traditional expectations placed on women. Benevolent sexism, on the other hand, rewards compliance with the status quo (Sibley \& Wilson, 2004).

The failure of Hillary Rodham Clinton in the 2016 presidential elections could be interpreted as consistent with this theory. Research shows that when people think "leader", they think "man" (Sczesny, 2003). Thus, leadership is not consistent with the traditional female role. Female leaders' skills are therefore often questioned - Hillary Rodham Clinton, Theresa May and Margaret Thatcher are only some examples. On the other hand, traditional "good" women, including celebrity cooks like Mary Berry - an elderly (grand)motherly figure - are socially rewarded. Hillary Rodham Clinton was thus a likely target of hostile sexism (this could help to account for opposition to her not only from the right but also from the left - see Francis, 2018).

Importantly, sexism is not politically neutral. Research shows that sexism and racism were the best predictors - better than authoritarianism - of voting for Trump (Valentino, Wayne \& Oceno, 2018) and hostile sexism specifically was the second strongest predictor after general political orientation (Glick, 2019). Crucially, women are socialised to endorse sexism and their sexism is higher in strongly sexist cultural contexts (Zawisza, Luyt \& Zawadzka, 2015). The presence of Trump with his misogynistic views arguably made the election climate more sexist (Zucker, Weis \& Richman, 2019). This in itself may have contributed to women's higher sexism which 
manifested in the high percentage of women supporting Trump despite his infamous sexism.

Interestingly, sexism also increases in women when the prosperity of the country is threatened. For example, Norwegian women choose "macho men" (over a "nice guy") on dating websites when they are informed that the country is under threat. When the country is prosperous, Polish women choose communal (gender atypical) over agentic (gender typical) men (Kosakowska-Berezecka \& Besta, 2016). Let's not forget that Trump's voting campaign occurred against the backdrop of a recent global financial crisis. It also largely focussed on terrorism, which was linked with immigration concerns, painting a picture of high threat to the country. This may have mobilised bluecollar women to vote for the "macho man" Trump exemplifies and not for another (atypical) woman. In comparison with white-collar women, women from this background might be argued to inhabit more sexist environments and depend more on men economically.

In sum, white women who supported Trump may well have been responding to heightened cultural sexism and perceived national threat. They might have felt that the only way they could achieve safety and betterment was via endorsing benevolent sexism: i.e. by securing protection from powerful men such as Trump, even at the cost of submission to such men. Higher cultural sexism reinforces traditional views of women as vulnerable and in need of help from strong protectors. It also punishes transgressions from traditional prescriptions that women should be submissive. Couple this with the "imminent" threat to the country and you have a great recipe to motivate women to follow the ultra-masculine protector'. 


\section{Discussion}

This discussion is structured around the overarching theme of 'safe identities'. This theme was identified both in the panel contributions and subsequent debate. It comprises three subthemes: 'threatening identities', 'safety through the status quo' and 'safe academic identities'.

\section{Safe identities}

The panellists described in various ways how some women and LGBTQ+ people are inclined to support right-wing populism in order to claim 'safe identities'. Safety relates variably to certainty, sameness, protection, maintaining traditional values or power structures and neutralising difference.

\section{Threatening identities}

The panellists, albeit from different theoretical perspectives, suggested that right-wing populist ideology appeals to disempowered social groups such as women or sexual minorities due to the succour it offers against various perceived 'threats'. For example, the panellists referred to the perceived threats, and associated imagined groups, of radical Islam (Ashley Brooks), immigration (Daragh McDermott and Magdalena Zawisza-Riley), autonomy (Ashley Brooks), threats of gender radicals (Ashley Brooks and Sam Martin), lack of prosperity (Russell Luyt and Magdalena Zawisza-Riley), and strong women in leadership roles (Magdalena Zawisza-Riley). Support for right-wing populism and populists is perceived as offering safety through 'ordinary', traditional, dominant (gendered) identity positions. Both Ashley Brooks and Sam Martin described empirical findings relating to LGBTQ+ people differentiating or distancing themselves from other (real or imagined) LGBTQ+ people in order to lay claim to safe identities, or 
distance themselves from threatening Others. The theme 'threatening identities', which has been implicated in populist rhetoric elsewhere (Sakki \& Pettersson, 2016), arose particularly prominently in Ashley Brooks' contribution.

Brooks focussed on the threats posed to LGBTQ+ identities by liberal activism and the framing of LGBTQ+ people as victims. We appreciate that 'liberalism' is a historically and contextually contingent as well as developing and conceptually rich term; this seem amply in differences between European and American political discourse concerning the term 'liberal'. Yet what unites the use of the term is a focus on the rights and freedoms of the individual (Freeden \& Stears, 2013). It is therefore interesting that the label 'liberal' is often used to refer to ideologies and practices which are seen to limit these rights and freedoms.

Safe identities and the threat of liberalism was echoed in Sam Martin's contribution. However, in this context, liberalism signalled the deconstruction of essentialist gender categories seen in, for instance, the increasing availability of nonbinary discursive resources. This is evidently experienced as threatening by some people. It has, more recently, emerged as a contentious issue in the US and the UK with examples of Trump and other right-wing populists trying to enforce binary and essentialist notions of gender through (re)legislation (Cahill \& Makadon, 2017). Similar arguments are seen in Magdalena Zawisza-Riley's contribution, where she points to the threat posed by Hillary Rodham Clinton who, as a female leader, transgresses norms of femininity (see also Francis, 2018).

The first subtheme therefore describes how safe identities can be positioned in opposition to, or protection from, a threatening Other. The safety offered by populist figures emanates from identity positions they offer vis-à-vis particular threatening Other 
identity positions. Right-wing populism appeals to ordinary and traditional values in the hope of preserving established gender relations.

\section{Safety through the status quo}

The second subtheme concerns how right-wing populist ideologies appeal to people, often socially disempowered, through reinforcing the perceived identity safety of the status quo. This theme does not concern the actual status quo, but rather its comparison to an imagined 'better time', and how this is received by people in relation to support of right-wing populism. Contributors note that many of the threats proffered by populist figures signal departure from the gendered (masculinist) status quo that is often framed as traditional and ordinary and is taken-for-granted. Disempowered social groups, such as women or sexual minorities, are rewarded through acquiescence with the status quo or punished for transgressing related norms.

Sam Martin spoke about the appeal of the 'ordinary position' within LGBTQ+ communities, as a safe identity that serves to maintain the status quo. The appeal of the ‘ordinary position' for many LGBTQ+ people, who assume it increases acceptance from the general public, has arguably resulted in legal reform that has afforded rights and entitlements to these communities. Moreover, there is also safety in invisibility through not providing an overt target for prejudice and discrimination. Daragh McDermott discussed how the politician Leo Varadkar maintains the status quo, in spite of his gay identity. He suggested that Varadkar draws on populist tropes in order to increase his political appeal. There is a considerable self-interest in being seen as ordinary, particularly for a gay and ethnic minority leader in a traditionally conservative country. 
The way in which LGBTQ+ people make themselves 'ordinary' was considered further in the chaired debate. In maintaining the status quo in this way, LGBTQ+ often sanitise, and in some cases seek to eradicate, difference. As Daragh McDermott put it,

[...] when one examines the literature on attitudes towards sexual minorities, it's apparent that people's attitudes towards (them) can be quite progressive as long as there's no sex involved. For example, an individual can identify as gay [...] but as soon as they are seen holding hands, kissing, or even the idea of having any kind of sexual intercourse with another man, then it elicits a much more visceral, emotive, disgust-based response. Within the Irish context [...] you have [...] an openly gay Prime Minister, who doesn't seem to have a personal life in the same way that other politicians do. While Varadkar does have a partner, he rarely engages in any kind of political or state events in the same way that a first lady would be expected to. There is a sanitised version of his identity to make it acceptable.

In order not to disrupt the status quo, Leo Varadkar adopts a 'safe' gay identity which involves eradicating any association with sexuality. Conversely, we could supply examples of LGBTQ+ politicians who are open about their private lives (e.g., former Scottish Conservative Party leader Ruth Davidson). This suggests that adopting a 'safe' gay identity - or not - is a strategy. This corresponds with arguments offered by Sam Martin, in which certain groups within the LGBTQ+ community are seen to 'take things too far' for more traditional community members. In this case, identity threat emanates from gender radicals taking it 'too far' from the traditional, ordinary, and taken-forgranted. Magdalena Zawisza-Riley likewise highlighted how non-normative gender 
identities are punished and normative ones rewarded. This, she argues, can be seen to be a key factor in why women support right-wing populist leaders.

\section{Safe academic identities}

The final subtheme relates to the concern that academia is being too 'safe' and needs to pose more of a conscious challenge to right-wing populism. The notion of safe academic identities encapsulates discussion relating to academia's complicity with the rise of right-wing populism through the relative absence of their active leadership and, at times, complicity with neoliberal ideology.

Russell Luyt spoke of retrogressive change in the gender order and the relative lack of impactful progressive challenge posed by academia. He argued that this is due to failure in ideological leadership by academia who inhabit a privileged position in ideological reproduction. Academia is not posing sufficient challenge to right-wing populism through, in part, adopting safe academic identities, which are sustained through complicity with, and material and psychological (identity) reward through, neoliberalism.

It was suggested during the chaired debate that an aspect of safe academic identities is the lack of engagement with real world ideas and reliance on abstract theoretical concepts that are inaccessible to the general public. Magdalena ZawiszaRiley contributed:

$[\ldots]$ historically in academia $[\ldots]$ there has been a lot of emphasis on theory, and neglect of the applied. I wonder whether that's also part of the problem, whether we, as academics, became very comfortable talking about very abstract theoretical concepts, which perhaps are not easy to understand generally, and we 
forgot to ask the question of the 'so what?' - how are our understandings relevant to everyday life and how may they be translated? Have we done enough translation?

Likewise, Daragh McDermott stressed the inaccessibility of academic work. He challenged the academic community to move beyond what was safe and seek out new ways of communicating with the public on their own terms, adding:

But the other point is that $[\ldots]$ using Brexit as an example, part of the campaign was 'We don't want to hear from experts, we're done with experts', and the failure on our part was $[\ldots]$ because of its complexity (we), those with other forms of knowledge, didn't then try and account for it in a much more accessible way that articulated with everyday realities.

Of course, scepticism of 'experts' and 'the elite' are core features of populist discourse. It is interesting that these notions were drawn upon by academics themselves in the discussion. Relatedly, these ideas also surface in the current focus on 'impact' in academia (see Terämä, Smallman, Lock, Johnson \& Austwick, 2016). Some might point to the fact that the failure of individual academics to effect change is a consequence of the structures - economic, organisational, societal - that they find themselves in. This in itself might be considered a safe position to take - or identity to adopt; where one constructs the self as lacking in agency. Others might argue that the whole notion of academics failing to prevent the rise of right-wing populism rests on the assumption that everyone would agree that 'progressive is best', if only they 
understood. The perceived paternalism, discussed in relation to the first theme of ‘threatening identities', rings particularly loudly in such arguments.

\section{Theoretical implications and future directions}

Reactions against progressive social change are characteristic of right-wing populism and involve the scapegoating of an imagined 'leftist elite' and beneficiary minority groups (Greven, 2016). This idea is captured across the themes. In liberal Western democracies, the political 'right' and 'left' commonly believe that individual rights and freedoms are best secured in different ways: protecting versus claiming liberty respectively (Janoff-Bulman, 2009). The political left is, nonetheless, ordinarily associated with liberalism. These political traditions have meant that neoliberal economic policies - including market freedom and deregulation - found a natural home within the political right. Such policies have had a devastating impact on many communities, and in particular the already disadvantaged (Theodore, 2019). It is therefore ironic that these communities have turned to history and tradition - the domains of the right - seeking a sense of community which was once enabled by the social movements and institutions of the left. And so, the reaction from disadvantaged groups against liberalism may be argued to be a misdirected reaction against neoliberalism (Norris \& Inglehart, 2018).

Right-wing populism appeals to people because it frames problems in simple terms - the notion of someone (or groups) gaining at our expense. Walzer (1984) argues that in response ' $[\ldots]$ we should aim, not at the freedom of the solitary individual but at what can best be called institutional integrity' (p. 325), by focussing on shared social projects. Seminal work in Realistic Group Conflict Theory in fostering superordinate goals (e.g., Gaertner et al., 2000) and Social Identity Theory in engendering 
superordinate identity are (Tajfel \& Turner, 1986), ${ }^{1}$ perhaps a useful starting point in a collective effort to claim safe identities that askew the appeal of right-wing populism.

'Stereotype threat theory' (Steele \& Aronson, 1995) repeatedly emerges in literature searches relating to the broad concept of identity safety. Yet it is important to note that this is not akin to the theme of 'threatening identities' discussed earlier. The theme of threatening identities relates to right-wing populist ideology offering 'safety' from perceived threats posed by different groups of people, whereas the concept of stereotype threat is defined as follows:

When negative stereotypes targeting a social identity provide a framework for interpreting behavior in a given domain, the risk of being judged by, or treated in terms of, those negative stereotypes can evoke a disruptive state amongst stigmatized individuals. This situational predicament, termed stereotype threat, can undermine stigmatized individuals' performance and aspirations in any targeted domain (Davies, Spencer \& Steele, 2005, p. 277).

One might argue that stereotype threat could be applied in making sense of why minority group members 'other' their in-group (i.e. that this behaviour is driven by a fear of confirming stereotypes). To this end, the definition above could be extended to

${ }^{1}$ Tajfel himself did not recognise the value of applying Social Identity Theory to the study of gendered phenomena, although this endeavour was taken up later by a number of women who had studied under his supervision. Notably, allegations of sexual misconduct have recently clouded his psychological heritage (Young \& Hegarty, 2019). 
include 'the stigmatisation of others sharing the same social identity' as a consequence of stereotype threat.

There is also an associated literature on 'identity safety' which is concerned with the creation of 'identity safe' spaces, such as classrooms, where threatening stereotypes are not made relevant. This could yield some useful insights in terms of applied practice and effecting social change. However, the concept of identity safety is currently somewhat under-theorised. Moreover, both these literatures are firmly rooted in the social cognition tradition and would need substantial reinterpretation to encompass multiple social psychological perspectives.

Another applicable theory is Breakwell's (1986) 'threatened identities'. Breakwell lists various core 'principles' relating to identity: continuity (across time and situations); self-esteem (the need to feel personally and socially worthwhile); uniqueness (in comparison to others); self-efficacy (belief in one's abilities). When one or more of these are deemed to have been challenged, threat is experienced, which in turn impacts identity. It is possible that applying or extending Breakwell's theory may be useful in making sense of the phenomena described in this paper. For example, there are obvious links between the idea of 'continuity' and 'safety through the status quo' (although, perversely, right-wing populism aims to disrupt the status quo - albeit by contrasting it with an imagined better past). Moreover, 'self-esteem' could be considered to be a factor in both paternalism (protecting others allows one to claim social value) and in its rejection (victimhood does not), and so relate to both 'safe academic identities' and 'threatened identities'. 'Uniqueness' is interesting, because right-wing populism tends to homogenise 'the people' it claims to champion (Greven, 2016) - something which manifested in the claims to ordinariness described by Sam Martin. And 'self-efficacy', 
and indeed self-esteem, can be imagined to have come under threat in the current economic climate of globalisation and technological advancement.

\section{Conclusion}

This paper aimed to consider how different social psychological perspectives account for the phenomenon of support for right-wing populists by (gender and sexual) minority group members. In so doing, it identifies common and divergent explanations, novel interdisciplinary insights, and areas for future development.

As social psychologists, we agree that it is likely that people who support rightwing populists are often reacting against perceived threats to the self - be they in relation to progressive change relating to culture (see Norris \& Inglehart, 2018), economics (see Mols \& Jetten, 2016), or a range of other factors. What is different about movements such as 'Gays for Trump' and '\#WomenWhoVoteTrump' is that the people who are reacting in this way are from groups who stand to benefit from such change (i.e. sexual minority members and women).

Panel members accounted for this in different ways which corresponded with their varying theoretical perspectives. A key theme which ran through the panellists' contributions was that right-wing populism offers 'safe' identities - be these, for example, economically, personally, physically, psychologically or socially motivated. One of the core messages identified from the panel's contributions was how right-wing populism plays on peoples' anxieties and fears in different ways and encourages movement toward what is considered safe. Safety is, for most people, what is traditional, ordinary, taken-for-granted and comfortable.

Contributors also considered the rejection of victimhood by minority groups as an explanation of the endorsement of right-wing populist ideologies, in terms of the 
perceived threat of paternalism. This position draws upon and feeds into the mistrust of 'experts' which is a prominent feature of such ideologies. The panel therefore threw down the gauntlet: the time for safe identities, including instances in which we as academics may be complicit, must be challenged - we must rise to the challenge, and in so doing, mount a self-critical, decisive, impactful, but most importantly, accessible challenge to right-wing populism.

References

Arbour, B., \& McGowen, E.B. (2017). Let me tell you a little bit about myself: Biographical appeals in congressional general election campaign advertising. Politics and Policy, 45, 224-252.

Berlet, C., \& Lyons, M.N. (2000). Right-wing populism in America: Too close for comfort. New York, NY: Guilford Press.

Braun, V., \& Clarke, V. (2006). Using thematic analysis in psychology. Qualitative Research in Psychology, 3(2), 77-101.

Breakwell, G.M. (1986). Coping with threatened identities. London: Metheun.

Brooks, A.S., Luyt, R., Zawisza, M., \& McDermott, D.T. (Submitted). Ambivalent homoprejudice towards gay men: Theory development and validation.

Cahill, S.R., \& Makadon, H.J. (2017). If they don’t count us, we don’t count: Trump administration rolls back sexual orientation and gender identity data collection. LGBT Health, 4(3), 171-173.

Choma, B.L., \& Hanoch, Y. (2016). Cognitive ability and authoritarianism: Understanding support for Trump and Clinton. Personality and Individual Differences, 106, 287-291. 
Clarke, V., \& Smith, M. (2015). "Not hiding, not shouting, just me": Gay men negotiate their visual identities. Journal of Homosexuality, 62(1), 4-32.

CNN. (2016). Exit polls. Retrieved from https://edition.cnn.com/election/2016/results/exit-polls

Connell, R.W. (1987). Gender and Power: Society, the Person and Sexual Politics. Cambridge, England: Polity Press.

Connell, R.W. (1998). Masculinities and Globalization. Men and Masculinities, 1, 3-23.

Cranley, E., \& Mark, M. (2018, September 27). Here are all the sexual-misconduct allegations against Brett Kavanaugh. Business Insider. Retrieved from https://www.businessinsider.com/brett-kavanaugh-sexual-assault-misconductallegations-2018-9? $\mathrm{r}=\mathrm{US} \& \mathrm{IR}=\mathrm{T}$

Davies, P.G., Spencer, S.J., \& Steele, C.M. (2005). Clearing the air: Identity safety moderates the effects of stereotype threat on women's leadership aspirations. Journal of Personality and Social Psychology, 88, 276-287.

Demetriou, D.Z. (2001). Connell's concept of hegemonic masculinity: A critique. Theory and Society, 30, 337-361.

Duggan, L. (2002). The new homonormativity: The sexual politics of neoliberalism. In R. Castranovo \& D.D. Nelson D.D. (Eds.), Materializing democracy: Toward a revitalized cultural politics (pp. 175-194). Durham, NC: Duke University Press.

Fitzsimons, T. (2018, August 21). Meet Brandon Straka, a gay former liberal encouraging others to \#WalkAway from Democrats. NBC News. Retrieved from https://www.nbcnews.com/feature/nbc-out/meet-brandon-straka-gay-former$\underline{\text { liberal-encouraging-others-walkaway-democrats-n902316 }}$ 
Francis, R.D. (2018). Him, not her: Why working-class white men reluctant about Trump still made him President of the United States. Socius: Sociological Research for a Dynamic World, 4, 1-11.

Freeden, M., \& Stears, M. (2013). Liberalism. In M. Freeden, L.T. Sargent, \& M. Stears (Eds.), The Oxford handbook of political ideologies (pp. 329-347). Oxford: Oxford University Press.

Gaertner, S.L., Dovidio, J. F., Banker, B. S., Houlette, M., Johnson, K.M., \& McGlynn, E. A. (2000). Reducing intergroup conflict: From superordinate goals to decategorization, recategorization, and mutual differentiation. Group Dynamics: Theory, Research, and Practice, 4(1), 98-114.

Ghaziani, A., Taylor, V., \& Stone, A. (2016). Cycles of sameness and difference in LGBT social movements. Annual Review of Sociology, 42, 165-183.

Glaser, E. (2018). Anti-Politics: On the demonization of ideology, authority and the state. London: Repeater.

Glick, P., \& Fiske, S.T. (1996). The ambivalent sexism inventory: Differentiating hostile and benevolent sexism. Journal of personality and social psychology, 70(3), 491.

Glick, P., \& Fiske, S.T. (2011). Ambivalent sexism revisited. Psychology of Women Quarterly, 35(3), 530-535.

Glick, P. (2019). Gender, sexism, and the election: did sexism help Trump more than it hurt Clinton? Politics, Groups, and Identities, 1-11.

Gramsci, A. (1929-1935, 1996). The Prison Notebooks (Q. Hoare \& G.N. Smith, Trans.). London, England: Lawrence and Wishart.

Habermas, J. (1975). Legitimation Crisis (T. McCarthy, Trans.). Boston, MA.: Beacon Press. 
Inglehart, R.F., \& Norris, P. (2016). Trump, Brexit, and the rise of populism: Economic have-nots and cultural backlash. HKS Faculty Research Working Paper Series No. RWP16-026. Retrieved from:

https://research.hks.harvard.edu/publications/workingpapers/Index.aspx

Janoff-Bulman, R. (2009) To provide or protect: Motivational bases of political liberalism and conservatism. Psychological Inquiry, 20(2-3), 120-128.

Jeffreys, S. (2014). Gender hurts: A feminist analysis of the politics of transgenderism. New York, NY: Routledge.

Kentmen-Cin, C., \& Erisen, C. (2017). Anti-immigration attitudes and the opposition to European integration: A critical assessment. European Union Politics, 18(1), 325.

Kosakowska-Berezecka, N., Besta, T., Adamska, K., Jaśkiewicz, M., Jurek, P., \& Vandello, J.A. (2016). If my masculinity is threatened, I won't support gender equality? The role of agentic self-stereotyping in restoration of manhood and perception of gender relations. Psychology of Men \& Masculinity, 17(3), 274.

Major, B., Blodorn, A., \& Blascovich, G.M. (2016). The threat of increasing diversity: Why many White Americans support Trump in the 2016 presidential election. Group Processes \& Intergroup Relations, 21(6), 931-940.

Marchlewska, M., Cichocka, A., Panayiotou, O., Castellanos, K., \& Batayneh, J. (2018). Populism as identity politics: Perceived in-group disadvantage, collective narcissism, and support for populism. Social Psychological and Personality Science, 9(2), 151-162.

McDonald, M.P. (2016). 2016 November general election turnout rates. Retrieved from http://www.electproject.org/2016g

Mencken, H.L. (1916). A little book in C major. New York: John Lane Company. 
Mudde, C. (2004). The populist zeitgeist. Government and Opposition, 39(4), 541-563.

Mudde, C., \& Rovira Kaltwasser, C. (2017). Populism: A very short introduction. Oxford University Press.

Mols, F., \& Jetten, J. (2016). Explaining the appeal of populist right-wing parties in times of economic prosperity. Political Psychology, 37(2), 275-292.

Norris, P., \& Inglehart, R. (2018). Cultural backlash: Trump, Brexit, and the rise of authoritarian populism. New York, NY: Cambridge University Press.

Norocel, O.C. (2017, December). Masculinities and right-wing populism across Europe: An intersectional perspective. Political Masculinities and Populism Conference. Universität Koblenz-Landau, Landau.

Parker, I. (1989). The crisis in modern social psychology. London: Routledge.

Pettigrew, T.F. (2017). Social psychological perspectives on Trump supporters. Journal of Social and Political Psychology, 5(1), 107-116.

Potter, J., \& Wetherell, M. (1987). Discourse and social psychology: Beyond attitudes and behaviour. London: Sage.

Rapley, M. (1998). 'Just an ordinary Australian': Self-categorization and the discursive construction of facticity in 'new racist' political rhetoric. British Journal of Social Psychology, 37(3), 325-344.

Reicher, S. (2012). From perception to mobilisation: The shifting paradigm of prejudice. In J. Dixon \& M. Levine (Eds.), Beyond prejudice: Extending the social psychology of conflict, inequality and social change (pp. 27-47). New York, NY: Cambridge University Press.

Röder, A. (2017). Old and new religious minorities: Examining the changing religious profile of the Republic of Ireland. Irish Journal of Sociology, 25(3), 324-333. 
Ryan, P. \& O’Connor, N. (2018). Leo: A very modern Taoiseach. London, England: Biteback Publishers.

Sacks, H. (1984). On doing ‘being ordinary’. In J. Heritage \& J.M. Atkinson (Eds.), Structures of social action: Studies in conversation analysis (pp. 413-429). Cambridge, UK: Cambridge University Press.

Sakki, I., \& Pettersson, K. (2016). Discursive constructions of otherness in populist radical right political blogs. European Journal of Social Psychology, 46, 156170.

Sczesny, S. (2003). The perception of leadership competence by female and male leaders. Zeitschrift fur Sozialpsychologie, 34(3), 133-145.

Shiffrin, S.V. (2000). Paternalism, unconscionability doctrine, and accommodation. Philosophy \& Public Affairs, 29, 205-250.

Sibley, C.G., \& Wilson, M.S. (2004). Differentiating hostile and benevolent sexist attitudes toward positive and negative sexual female subtypes. Sex Roles, 51(1112), 687-696.

Spillane, M. (2015). The Irish rainbow. Nation, 300(24), 5-8.

Steele, C.M., \& Aronson, J. (1995). Stereotype threat and the intellectual testperformance of African-Americans. Journal of Personality and Social Psychology, 69(5), 797-811.

Stewart, J., Mazzoleni, G., \& Horsfield, B. (2003). Conclusion: Power to the media managers. In J. Stewart, G. Mazzoleni, \& B. Horsfield (Eds.), The Media and Neo-Populism: A Contemporary Comparative Analysis (pp. 217-23). Westport, CT: Praeger.

Sue, D.W. (2010). Microaggressions in everyday life: Race, gender, and sexual orientation. Hoboken, NJ: John Wiley \& Sons. 
Tajfel, H., \& Turner, J.C. (1986). The social identity theory of intergroup behavior. In S. Worchel \& W.G. Austin (Eds.), Psychology of Intergroup Relations. Chicago, IL: Nelson-Hall.

Terämä E., Smallman, M., Lock, S. J., Johnson, C., \& Austwick, M.Z. (2016). Beyond academia - Interrogating research impact in the Research Excellence Framework. PLoS ONE 11(12): e0168533. https://doi.org/10.1371/journal.pone.0168533

Theodore, N. (2019). Governing through austerity: (Il)logics of neoliberal urbanism after the global financial crisis. Journal of Urban Affairs. Advance online publication.

Valentino, N.A., Wayne, C., \& Oceno, M. (2018). Mobilizing sexism: The interaction of emotion and gender attitudes in the 2016 US presidential election. Public Opinion Quarterly, 82(S1), 799-821.

Varadkar, L. (2017, April). Welfare cheats cheat us all. Department of Employment Affairs and Social Protection. Retrieved from https://www.welfare.ie/en/pressoffice/Pages/pr180417.aspx

Walzer, M. (1984). Liberalism and the art of separation. Political Theory, 12(3), 315330.

Wolffe, R. (2018, July 1). Donald Trump's only fixed position on abortion is his disdain for women. The Guardian. Retrieved from https://www.theguardian.com/commentisfree/2018/jul/01/donald-trump$\underline{\text { abortion-supreme-court }}$

Young, J.L., \& Hegarty, P. (2019). Reasonable men: Sexual harassment and norms of conduct in psychology. Feminism \& Psychology, O(0), 1-22. 
Zawisza, M., Luyt, R., \& Zawadzka, A.M. (2015). Societies in transition: Are they more sexist? A comparison between Polish, South African and British samples. Journal of Gender Studies, 24(1), 38-55.

Zucker, A.N., Weis, A.S., \& Richman, L.S. (2019). Grab 'em by the masculinity: Changes in gendered beliefs and sexism following the 2016 US presidential election: Part of "Themes of Gender and Identity in the 2016 US Presidential Election.” Politics, Groups, and Identities, 1-11. 